\title{
Space - more a question of pride
}

DOES India need a space programme? Ask Dr U. R. Rao, the chairman of the Space Commission, and you are left in no doubt: India needs a capability to launch satellites just as much as it needs, say, potable drinking water in every village. Indeed Rao, by his own voluntary admission a "powerful" man, goes a long way to suggest that there will not be drinking water in every village without a space programme.

And an independent one. Rao, who is charming and intelligent as well as powerful, does not want India to be pushed about. He offers as illustration of how India can be ill-treated the case if the recent Russian refusal to transfer the technology for building cryogenic (liquid hydrogen) rocket engines, widely believed to be the result of US pressure. "Who in his senses would think that people would use cryogenic engines in military rockets?", he asks.

Speaking at the satellite laboratory of the Indian Space Research Organization (ISRO) at Bangalore at the end of last month, Rao was clearly looking forward to the visit the following week of a delegation from Russia bent on renegotiating the contract to transfer the cryogenic technology. Contrary to the expectations of his colleagues that he would make a fuss, he declared ominously that he would "listen to what they have to say". Meanwhile, to judge from the public construction tenders being advertised in the newspapers, India is pushing ahead with its cryogenic facility, with or without Russian help.

So is there a military rocket programme? Rao reports a tense conversation with US defence people complaining that "half a dozen" ISRO engineers had recently joined the defence ministry. "I told them that many more had gone to work for NASA in the same period." Even so, it is only prudent to suppose that there are military as well as civilian rockets, and that the knowhow gained in developing the latter is somehow transferred. But ISRO's activities are otherwise transparent. And Rao has a persuasive case for

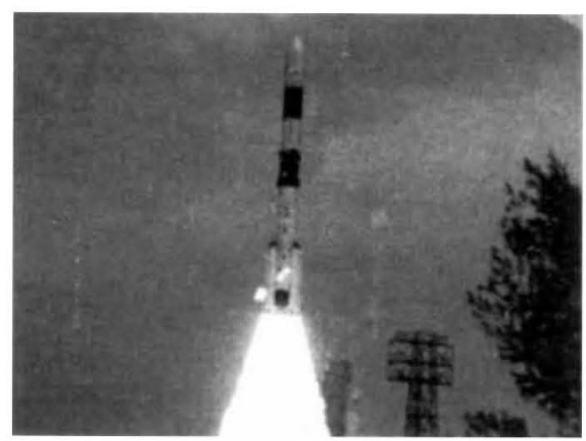

India's largest launcher, for $1,000 \mathrm{~kg}$ payload, launched in September.

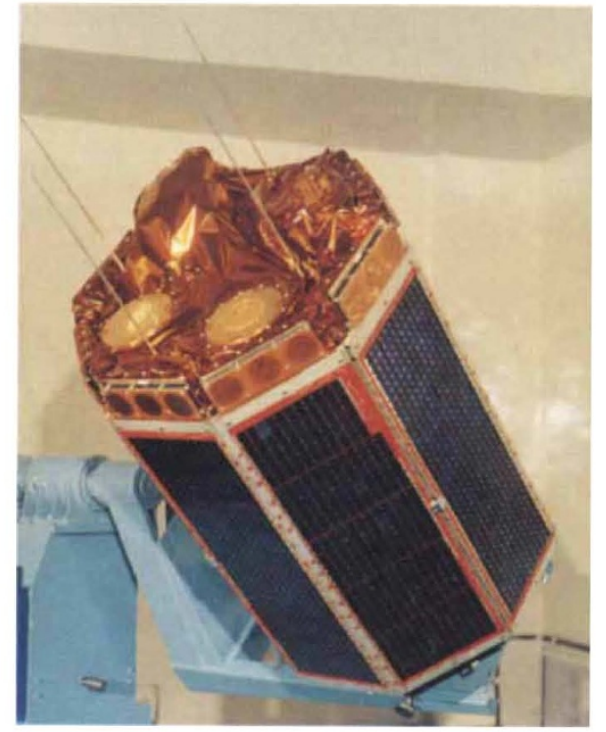

One of the extensive ISRO satellite family

linking Earth satellites with water for the villages.

India's practical interest in Earth satellites is two-fold: communications and Earth observation. There are ample practical successes to boast of, not least the use of a geosynchronous transponder to provide warning of impending typhoons to a clutch of unattended monitoring stations on the coast of the Bay of Bengal. Rao says that the Disaster Warning System saved 20,000 lives from a typhoon that struck in November 1991. (This is the typhoon season of the year.)

Ingenuity, with the sense of improvisation that inevitably brings, has been a hallmark of the Indian space programme ever since Vikram Sarrabai's people at Ahmedebad in the late 1960 s temporarily used a US satellite to send television signals to a few Indian villages. Rao is now hoping to institutionalise that old "SITE" project with six to eight high-power Cband transponders in a satellite system called GRAMSAT - "Gram" is Hindu for "village" - meant to get rid of illiteracy and provide continuing education as well as open university instruction, in a dozen or so native languages. The hope is to reach 90 per cent of the population through $80-\mathrm{cm}$ dishes within five or six years.

ISRO's Bangalore laboratory has become the home of many other semiautonomous providers of satellite-based services. In a country so big, mere geography is best done from Earth orbit, which the schemes for monitoring land use (by different crops, for example) and flooding (during monsoons), and for their improvement and abatement respectively. ISRO cut its teeth on US and then French ("SPOT") satellite images, but now proudly collects its own from the IRS-A (launched by an Ariane rocket in 1991) and IRS-B satellites, each of which collects images in one infrared and three optical wavebands.

The neatest application so far is the use of sea-surface images to spot the dividing lines between warm and cold offshore water, where fish are most likely to be found. A warning system has been set up, which has in turn provoked a typically Indian quarrel; the smaller fishermen are asking that they should be given the first advice because their boats are smaller, and take longer to reach the designated fishing opportunities. That is the kind of imagined injustice that the politicians will be eager to get their teeth into; ISRO, which wants to resist, is lucky to have Rao on its side.

The launcher business is India's real worry. Its ambitions have always lagged behind its hardware. At the outset of the space programme in 1963, it borrowed sounding rockets and learned the hard way about telemetry, but was building its own by the end of the decade. The decision to build a four-stage rocket (SLV-3) capable of launching $40-\mathrm{kg}$ satellites was taken in 1969 and carried through by 1980 - by which time it was clear that $40 \mathrm{~kg}$ in near-Earth was to little to serve much purpose and a decision had already been taken to build and even larger four-stage rocket - ASLV (for Augmented Satellite Launch Vehicle). No there is an even larger one nearing completion, called PSLV (for Polar Satellite Launch Vehicle); there was an unsuccessful first launch earlier this year. But even that will not put substantial communications satellites into geosynchronous orbit, whence the Russian cryogenic fourth stage.

For a country established as the firework Eldorado of the Third World - Indian fireworks sell even in China, but are believed to owe their cheapness to the low wages of the children used to make them around southern cities - that is galling. Rao says it is even worse: now that the Russians have agreed not to undercut the United States in launch costs, Ariane's costs have also come into line. He is also peppery about the asymmetry of the contracts the commercial launchers demand: customers incur penalties if their satellites are delivered late, but may then have to "twiddle their thumbs" for months while the launching rocket is made ready.

Given all that, the chances are high that India will continue to develop its own launch vehicles, to the irritation of developed countries who ask that the money should be given to the poor instead. That opinion neglects India's jealous pride in its independence, which in this context seems appropriate. The hope, instead, should be that the price will not be excessive. 